\title{
The Lower Paraguay river-floodplain habitats in the context of the Fluvial Hydrosystem Approach
}

\author{
Edmundo C. Drago ${ }^{1}$, Karl M. Wantzen ${ }^{2}$, Aldo R. Paira ${ }^{1}$ \\ ${ }^{1}$ Instituto Nacional de Limnología (CONICET-UNL), \\ J. Macia 1933, 3016 Santo Tomé, Santa Fe, Argentina. \\ e-mails: edmundodrago@arnet.com.ar; alpaira@eride.gov.ar \\ 2Max-Planck-Institute for Limnology, Tropical Ecology Work Group, \\ 24302 Plön, Germany and University of Konstanz, 78467 Konstanz, Germany. \\ e-mail: wantzen@mpil-ploen mpg.de
}

\begin{abstract}
We report herein the first description of the physical structure of the aquatic habitats of the Lower Paraguay River along $390 \mathrm{~km}$ from Asunción city (Paraguay) to the confluence with the Paraná River. The hierarchical ordination of the Fluvial Hydrosystem Approach (FHA) allowed us to classify the Lower Paraguay as a meandering functional sector where five functional sets were identified: (a) main channel, (b) floodplain channel, (c) floodplain lentic environment, (d) tributary, and (f) aquatic-terrestrial transition zone. These functional sets encompassed twenty one functional units and sixty one major mesohabitats. We attribute the riverine habitat diversity to the changes in the channel-floodplain morphology and in the strength, duration and frequency of their hydrological connectivity. The variable river-floodplain-tributary complex developed several types of fluvial-lacustrine boundaries and riverine ecotones.
\end{abstract}

Key words: Large river, physical habitat, connectivity, boundaries, ecotones.

\section{Introduction}

The Paraguay River forms an hydroecological corridor that crosses the central part of South America from the tropical headwater spring brooks at $15^{\circ} \mathrm{S}$ (closely linked with Amazonian headwater streams) to the subtropical zone of the confluence with the Paraná River $\left(27^{\circ} 17^{\prime} \mathrm{S}\right)$. Large parts of the upper and middle catchments of the Paraguay River contain one of the more important ecological regions of the world, the huge Pantanal wetland which in turn, regulates the hydrosedimentological regime of the Lower Paraguay segment (Drago et al. 2008, this issue Figs. 1 and 2).
While almost all large fluvial systems in the Northern Hemisphere have been regulated, the Paraguay River is still in a nearly pristine stage and may be useful as a natural model for restoration planning in similar systems of the tropical and subtropical zones. Moreover, insights from largely preserved river systems may be used to develop models for restauration planning in those rivers where pristine reference sites have been lost (Wantzen et al. 2005). Several studies in temperate rivers (Drago 1980, 1981, 1989, 2007; Amoros, Roux 1988; Baker et al. 1991; Ward, Stanford 1995; Arscott et al. 2000; Tockner et al. 2000; Pringle 2001; Amoros, Bornette 2002; Marchese, Ezcurra de Drago 1992; Marchese et 
al. 2002; Drago et al. 2003) as well as in tropical rivers (Hamilton, Lewis, Jr. 1987; Hamilton et al. 1996; Ezcurra de Drago et al. 2004; Marchese et al. 2005; Wantzen et al. 2005), identify fluvial landscape dynamics and connectivity betweeen main channel and floodplain as key factors in controlling habitat heterogeneity and biotic diversity. Few studies of this kind exist in neotropical rivers (e.g. Ezcurra de Drago et al. 2004; Marchese et al. 2005), however they are urgently needed as habitat destruction proceeds very fast (Wantzen et al. 2005).

The primary goal of this paper is to contribute to the physical characterization, hierarchical ordination and evolution trends of the aquatic habitats of the Lower Paraguay River (Drago et al. 2008, this issue Fig. 1), as well as the description of the major types of water-water boundaries and ecotones.

\section{Materials and methods}

\section{Functional classification}

As in previous papers (Drago et al. 2003; Wantzen et al. 2005) we adopt the hierarchical ordination of the riverine landscape structure developed in the Fluvial Hydrosystem Approach (FHA; Amoros et al. 1987; Petts, Amoros 1996). The target of this statement is to compare the fluvial segments or their different reach assemblages and the corresponding types of aquatic habitats that conform the Paraguay River hydrosystem (Wantzen et al. 2005). The remainder on this section as well as the site description has been developed in Drago et al. (2008 this issue). Measurements of the water temperature and salinity were made with a hand-held WTW series 300 probes, the turbidity with a Hach turbidimeter, and the water velocity with an AOTT current meter.

A functional sector describes river segments differentiated by changes in channel pattern- floodplain type, valley slope, width, and the confluence effect from tributaries with different water and sediment discharge and hydrochemistry. In the large South American rivers, the scale as well as the channel pattern of each functional sector or segment may vary greatly, sometimes largely overcoming $100 \mathrm{~km}$ in length. That is the case of the Paraguay River, where its upper segment shows an assemblage of reaches with different lengths and patterns (Wantzen et al. 2005). River sectors may be divided into functional sets (Petts, Amoros 1996) which are closely linked with specific fluvial geoforms as braided or meander reaches, abandoned meanders, ridge and swale topography, etc. The terms "reaches" or "stretches" are used as synonymous of functional sets for the shorter sections forming a segment or functional sector, which ranging from 5 to $100 \mathrm{~km}$ in length. In spite of that length ranges, they represent a uniform set of physical, chemical, and biological conditions within a large river segment. Because of that homogeneity in their environmental characteristics, they are usually chosen as the principal sampling units. Furthermore, the reach is also a common unit of field description among fluvial geomorphologists (Frissell et al. 1986; Amoros et al. 1987; Petts, Amoros 1996; Fitzpatrick et al. 1998). For example, the Lower Paraguay functional sector includes a $80 \mathrm{~km}$ long reach (from Bermejo mouth to the confluence with the Paraná), which is strongly affected by the high inputs of solid suspended load from Bermejo River (Drago et al. 2008 this issue, Fig. 1A,B). A functional set on the Lower Paraguay may develop an area as large as 4500 ha, as in the case of the Lake Herradura functional set, an abandoned meander of the main channel (Drago et al. 2008 this issue, Figs. 1, 3, 4). The character and evolution of each functional set within the fluvial segment is determined by the river-floodplain dynamics and the connection degree with the main channel or the active floodplain channels. For instance, the former floodplain areas remote from the Paraguay main channel are dominated by the rainfall, tributary input and groundwater seepage, and receive river water only during higher floods (Drago et al. 2008, this issue Figs.3, 5). The division of the functional units were based on a combination of the fluvial conditions of the site, as topographic slopes, water depth, and frequency and duration of the inundation and drought phases. In the cited case of the Lake Herradura set, functional units of the lake has a surface of 560 ha, whereas the marsh unit develops an area of ca. 2000 ha (Drago et al. 2008, this issue Figs. 1, 3: HL, 4: 7, 8, 9). The flow pulse (sensu Tockner et al. 2000) is also a very important factor to conditioning the functional units in short temporal scales. The hydro-functional classification of the lentic units was mainly based on their geomorphic connection and the degree of connectivity with the river water (Drago et al. 2008, this issuee Table I, Figs. 4, 5, 11,12, 13)

\section{Results}

The meandering-floodplain functional sector of the Lower Paraguay includes five functional sets which embraced twenty one functional units. Within these functional units, sixty one mesohabitats were delineated encompassing those located in the main channel as well as in the floodplain complex (Fig. 1.). However, we must stress that particular riverine areas often provide an ecologically distinct habitat at different water levels, as some minor temporary floodplain channels which may show lentic conditions during drought phases 


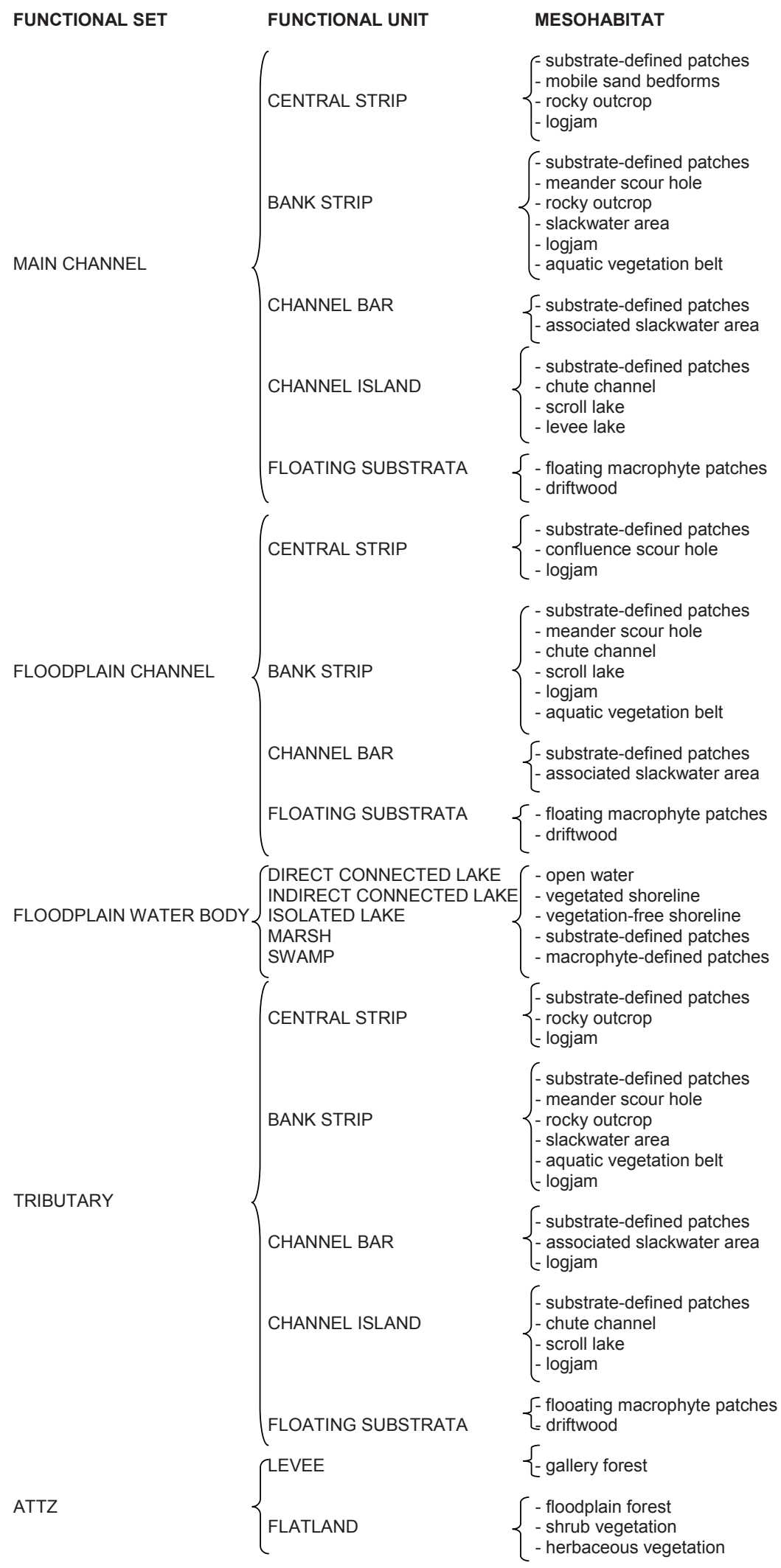

Fig. 1. Functional set, functional units and main related mesohabitats of the Lower Paraguay meandering sector. 
(Drago et al. 2003). Because of that, it is important to emphasize the composite nature of some fluvial habitats.

\section{Meandering-floodplain functional sector}

This functional sector encompasses the lower segment of the Paraguay River, being strongly affected in their physical and biological characteristics in the $80 \mathrm{~km}$ lowermost reach by the solid discharge of the Bermejo River. Furthermore, the high water stages mainly of the Paraná River as well as that of the Tebicuary and Bermejo rivers, generate noticeable upstream backwaters which hydrological effects may be observed until Asunción city. The functional sets, units and main mesohabitats will be defined in the following paragraphs.

\section{Main channel functional set and units}

Main channel functional set includes the meandering main channel and their chute channels (Fig. 1; Drago et al. 2008, this issue Figs. 3 and 4). This functional set includes the central channel strip unit that is the portion of the river encompassing in average the $95-98 \%$ of the wetted perimeter (Drago et al. 2003; Wantzen et al. 2005). Despite of this habitat shows changes in their physical parameters according with the season, river level, channel geometry and tributary inputs, the homogeneity of its bed texture is one of the key factors used for the alluvial river classification and zonation (Schumm 1977, 2005; Hynes 1970).

As in other large rivers (Drago 1984, Drago et al. 2003), channel habitat is characterized by a vertically and laterally homogeneous distribution of water temperature. The maximum differences detected between surficial and near-bottom waters did not exceed $1.5^{\circ} \mathrm{C}$, with the maximum temperature recorded in summer at $31^{\circ} \mathrm{C}$ (February) and the minimum in winter at $14^{\circ} \mathrm{C}$ (July). During the

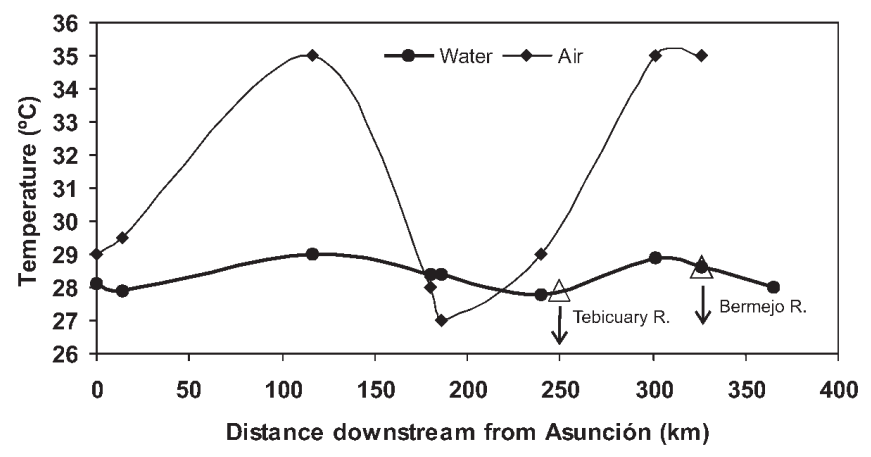

Fig. 2. Air and water temperature variations measured during the field trip. River temperatures were obtained at the channel center. Temperatures of Tebicuary and Bermejo rivers were taken $2 \mathrm{~km}$ upstream of their confluences with the Paraguay River. field trip in November 2001 (ten days from up- to downstream), we did not found longitudinal temperature variations, with the exception of that caused by the daily weather changes. Thus, river water temperatures showed small changes, between $27.8^{\circ} \mathrm{C}$ and $28.9^{\circ} \mathrm{C}$, where maximum and minimum water temperatures were associated with that of air temperatures (Fig. 2). The water temperature measured in the Tebicuary $\left(27.7^{\circ} \mathrm{C}\right)$ and Bermejo $\left(28^{\circ} \mathrm{C}\right)$ rivers were the same of the Paraguay River at their respective confluences. A study performed by HRS (1972) concluded that the Paraguay River increases its water temperature from upstream to downstream, and in the case of the Bermejo River, colder water is due to their origin in the Andes Mountains. In the first case, the slight increment of water temperature as the river flows further to the south, can be occurred only by the air temperature fluctuations. It seems quite logical because the Lower Paraguay segment flows within the subtropical area, and besides it does not receive warmer water tributaries. In the second case, our measurements indicate that Bermejo River increases its water temperature toward the confluence with the Paraguay River (Drago, Paira unpubl.), due to their flow along $1800 \mathrm{~km}$, from the cold-arid highlands of the Andes Cordillera to the subtropical dry lowlands of the Chaco-Pampa plain. Therefore, there is no probability that the Bermejo River joints the to Paraguay River maintaining the lower temperature of their cold headwater streams. Current velocity in the mid-channel ranges from $0.30 \mathrm{~m}$ $\mathrm{s}^{-1}$ under low discharges and exceeding often 2 $\mathrm{m} \mathrm{s}^{-1}$ at high streamflows. Fig. 3 shows the velocity fluctuations at the channel center as well as on the banks during low water phase (November 2001). In this case, the mean and maximum velocities at the mid-channel were 0.59 $\mathrm{m} \mathrm{s}^{-1}$ and $0.99 \mathrm{~m} \mathrm{~s}^{-1}$ respectively.

The low suspended mean sediment concentration measured in Asunción city $\left(68 \mathrm{mg} \mathrm{dm}^{-3}\right)$ reflect the sediment trap effect of the Pantanal. Further downstream, the sedimentological conditions of the Paraguay River changed due to the huge solid load injection of the Bermejo River. Thus, the high suspended sediment concentration $\left(858 \mathrm{mg} \mathrm{dm}^{-3}\right)$ measured in that tributary, sharply increased the suspended sediment concentration of the Paraguay River from $49 \mathrm{mg} \mathrm{dm}^{-3}$ to $313 \mathrm{mg} \mathrm{dm}^{-3}$ (Fig. 4A). Drago and Amsler (1988) showed that this increase is more than $600 \%$ on average (from $89 \mathrm{mg} \mathrm{dm}^{-3}$ to $576 \mathrm{mg} \mathrm{dm}^{-3}$ ) for the periods of maximum solid discharges of Bermejo River. The mean suspended sediment concentration in the Bermejo River was $6499 \mathrm{mg} \mathrm{dm}^{-3}$ with a maximum of $15 \mathrm{~g} \mathrm{dm}^{-3}$ in average (Amsler, 
Drago in press). However, the differences in water discharge between the Paraguay and Bermejo rivers (10.4:1), account for an important dilution of the high sedimentary delivery of the Bermejo River. Despite this dilution, the turbidity strongly increase from 44 to 266 NTU and the Secchi dis transparency falled from $0.4 \mathrm{~m}$ to $0.19 \mathrm{~m}$, from upstream to downstream of the Bermejo outlet respectively. The Secchi disk transparency measured at the mid-channel of the Bermejo River reached only $0.04 \mathrm{~m}$. The suspended and dissolved organic matter amounts also show a sharp increase downriver of the Bermejo mouth (Fig. 4B). From data of HRS (1972) we calculated that the Tebicuary River transports near the $20 \%$ of

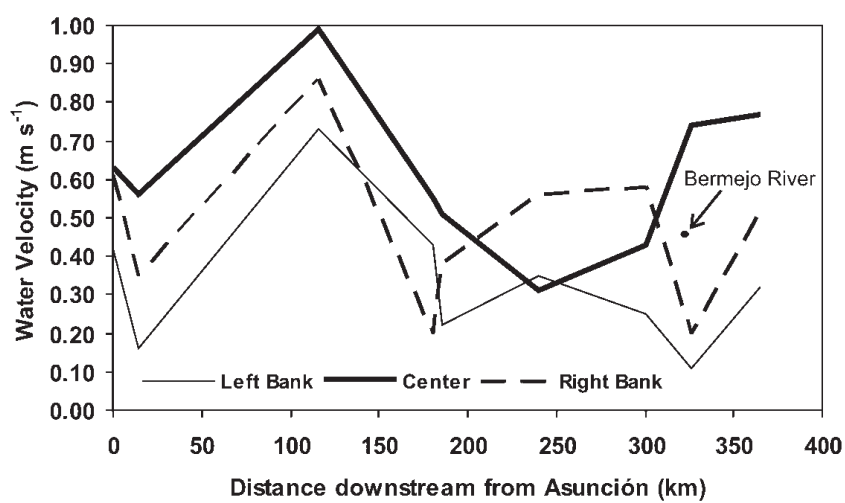

Fig. 3. Flow velocities variations along the main channel of the Lower Paraguay River. Current velocity of Bermejo River was taken at the center channel $2 \mathrm{~km}$ upstream of its outlet. its solid discharge as bed load. However, we measured a very low suspended sediment concentration $\left(0.043 \mathrm{~g} \mathrm{dm}^{-3}\right)$, which does not alter the wash load of the Lower Paraguay River (Fig. 4A).

The slow increase of the dissolved solids load along the Lower Paraguay, is mainly due to the contribution of saline waters through the Chaco-Pampean tributaries and groundwater seepage (Fig. 4A). These eastern tributaries
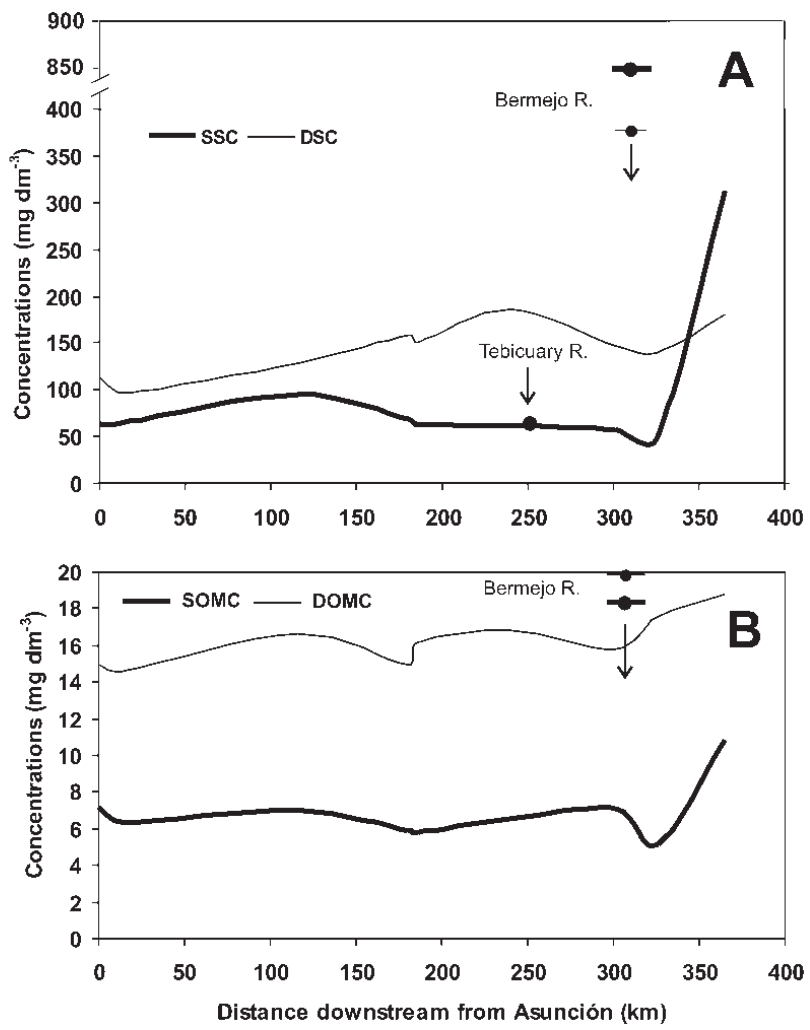

showed a mean salinity of $8 \mathrm{~g} \mathrm{dm}^{-3}$, reaching a maximum of $15 \mathrm{~g} \mathrm{dm}^{-3}$ during low stages (Lancelle et al. 1986). On the contrary, the western tributaries flowing toward the river valley, depicted salinities lower than $0.2 \mathrm{~g} \mathrm{dm}^{-3}$. Precisely, Fig. 4A shows a progressive increase of the Paraguay main channel salinity, and the sharp increment between $180 \mathrm{~km}$ and $250 \mathrm{~km}$ and again $325 \mathrm{~km}$ downstream of Asunción city was due to the salty tributaries of the ChacoPampa plain. The marked decreasing of salinity in the river reach located between $250 \mathrm{~km}$ and $325 \mathrm{~km}$ downstream of Asunción city, is due to the dilution effect of the water discharge of Tebicuary River together with is low water salinity $\left(0.080 \mathrm{~g} \mathrm{dm}^{-3}\right.$; Fig. $4 \mathrm{~A}$; Drago et al. 2008, this issue Fig. 1B). On the contrary, the dissolved solids of Bermejo River $\left(0.367 \mathrm{~g} \mathrm{dm}^{-3}\right)$ accounts for the increment of the salinity of the Paraguay River observed from $325 \mathrm{~km}$ downstream of Asunción city (Fig. 4A). The contribution of solids and dissolved materials from the eastern tributaries, with the exception of the Tebicuary River, are not so important as to change strongly the hydrochemistry and sedimentologic characteristics of the Lower Paraguay segment (Fig. 4A,B).

The bed sediments of the central strip unit were composed of sands that was always more than $81 \%$ of the sample, with maximum percentages of $99.6 \%$ (Fig. 5: S1-S9), being fine sand $(125 \mu \mathrm{m})$ the predominant grain size (Drago et al. 2008, this issue Fig. 7). However, the central strip showed changeable different sand fractions, e.g. very fine sand at S6 and S9 and coarse sands at S7 (Fig.5). The organic matter content was lower $(0.25-1.92 \%)$ than in

Fig. 4. A: Suspended sediment (SSC) and dissolved solid (DSC) concentrations. B: Suspended (SOMC) and dissolved (DOMC) organic matter concentrations. Data are from the main channel center. Data from Tebicuary and Bermejo rivers were obtained $2 \mathrm{~km}$ upstream of their outlets. the bank strips. The bed sediment of the lowermost reach of Bermejo River was composed by sand $(25.5 \%)$, silt $(38.7 \%)$ and clay $(35.8 \%)$, and in the sand fraction the largely 
overriding size was very fine sand (98\%). This fact and the hydraulic conditions generated by the confluence effect, clearly influence the fine sediment content of the bank strip sediments of the Paraguay main channel (Fig. 5: S8). Moreover, the bed sediment showed also a noteworthy increase in grain size composition, from $27 \%$ and $0.47 \%$ for fine and very fine sand respectively in S 8 to $33 \%$ and $67 \%$ for the same fractions respectively in S9 (Drago et al. 2008, this issue Figs. 1, 7). These data are similar to that found by Drago and Amsler (1998). The substrate was constantly shifting, and the channel bed was seldom flat with a bed configuration ranging from ripples to dunes (Drago et al. 2008, this issue Figs. 9 and 10). The most common active bed forms were located on the central strip habitat. The larger mesoforms $(\mathrm{H}>1 \mathrm{~m}-2.3$ $\mathrm{m})$ detected along the channel center presented an average height of $1.90 \mathrm{~m}$, showed superimposed smaller dunes on their upstream faces. Smaller dunes $(0.10-0.21 \mathrm{~m})$ were also measured on the sand beaches surrounding the islands and on the large emergent sand bars. On the sand bars, ripples $(\mathrm{H} \leq 0.05 \mathrm{~m})$ with linguloid and sinuous crest lines were also detected. Large densities of dunes ranging from 1.5 to $2 \mathrm{~m}$ in height were also detected at the double-heading meanders as that located 30 $\mathrm{km}$ downstream of Punta Itá Pirú (Drago et al. 2008, this issue Fig. 1). Even in quite deep water $(10-15 \mathrm{~m})$, the presence of these mesoforms was detected from the boils formed on the water surface downriver from the dune crests. Flat bed was only found in Puerto Las Palmas, located $20 \mathrm{~km}$ upstream of the Paraguay outlet (Drago et al. 2008, this issue Figs.1B: S9, 10C).
The bank strip unit is the parallel belt of variable width that occupies in average $2-5 \%$ of the wetted perimeter inshore the banks (Fig. 1.; Drago et al. 2008, this issue Fig. 8). This habitat is mainly affected by the channel geometry (both plan form and cross-section), inflow of tributaries, bank slumping and in a lesser degree by the floodplain channel outlets. Substrate quality is often a key factor to differentiate between central and bank strips, because bank strips usually displayed a major grain size heterogeneity and the silt and clay fractions tend to be dominant (Fig. 5). Bank strip sections with larger amounts of sands were usually found near lateral and scroll bars or sand-bed tributary outlets (Fig. 5: S1, S5, S6, S9), while banks overriding by fine sediments were commonly associated with slackwater areas, bank slumping or muddy tributary mouths (Fig. 5: S2, S4, S7, S8). The development of the bank strip unit was reduced along the contact with tectonic cliffs and in the outer margins of the meanders. On the contrary, the largest development were detected on the inner banks of the meanders at the point bars (Drago et al. 2008, this issue Fig. 8: B, C, D). Natural steep banks occurred on the cut bank sides of river bends, but also in some straight reaches. Slopes of natural steep banks were usually over $30^{\circ}$ and approached to vertical in sites of local active erosion, as in bends and tectonic bluffs (Drago et al. 2008, this issue Figs. 4: 24, 8: C, D). Higher percentages of silt-clay sediments in levees did not always reduce the bank erosion rates. When a silt-clay topstratum is underlain by an erodable sandy layer, bank slumping is frequent, as in the case of the floodplain

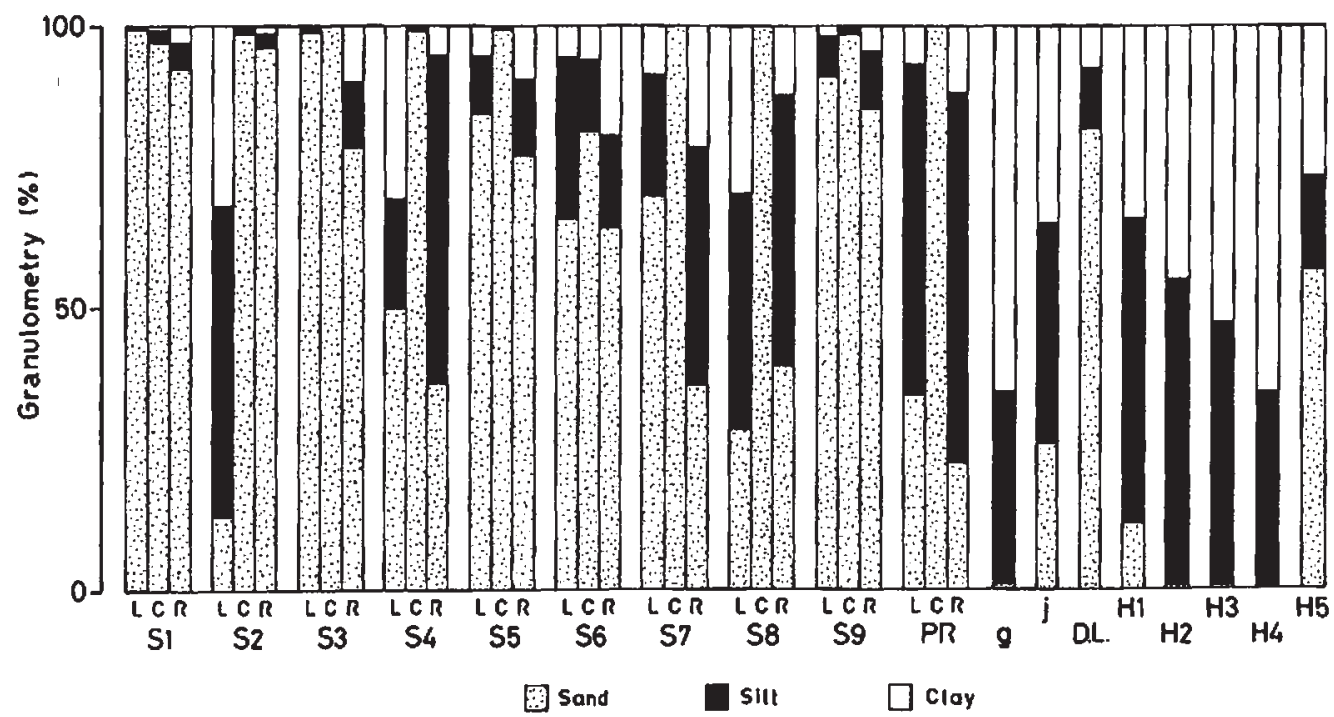

Fig. 5. Substrate composition of the channel beds and lake bottoms. Main channels of the Lower Paraguay River (S1-S9) and Paraná rivers (PR). L: left bank strip, C: center strip, R: right bank strip. Minor tributary: Salado River (g) and major tributary: Bermejo River (j). Small floodplain lake directly connected with the river at its downstream end (DL). Large oxbow indirectly connected with the river: Herradura Lake (H1-H5) (See Figs. 1 and 5 in Drago et al. 2008 this issue). 
edges where the attached bars had been covered by thick layers of fine sediment and vegetation during the annexation processes to the floodplain. This feature increases the sediment heterogeneity of the bank strip and the development of typical mesohabitats like fine substrate and logjam patches. Other mesohabitats closely associated with this functional unit are the scour holes and point bars (Fig. 1.).

Channel sand bars and islands units are common in-stream habitats along the Lower Paraguay. Bars are dynamic unvegetated macroforms that are submerged at bankfull stage. Islands are more stable features, emergent at bankfull stage and vegetated. Point and side bars were the typical sand formations in the Paraguay River (Drago et al. 2008, this issue Fig. 4: 14,19). The point and scroll bars are closely associated with the formation of the Lower Paraguay floodplain (Drago et al. 2008, this issue Fig. 4: 8, $15,16,17)$. The side bar occurs as attached bar in straight reaches and often also is detected upstream or downstream of bends. Some counterpoint bars have been identified occurring in slack-water areas where the channel is migrating rapidly and/or where a tight curve has developed (e.g., at the 'hairpin' meander of Formosa city, Argentina; Drago et al. 2008, this issue Figs. 1: S4 and 4). The Formosa city bend is a natural example of sediment activity in a $90^{\circ}$, short radius bend, where the acute curvature induces flow separation creating a reverse current (Rouse 1961) that deposits suspended sediments in the vortex on the concave side (fine sediment patch; Fig. 5: S4R) and a normal bar with bed sediment on the convex bank (Fig. 5: S4L-C; Drago et al. 2008, this issue Fig. 11A,B). Several examples of diagonal bars were also detected along the Lower Paraguay, originating sets of very shallow and parallel lakes or 'claw-like' scroll lakes, as that located on the left bank $5 \mathrm{~km}$ upstream of Formosa city, Argentina (Drago et al. 2008, this issue Figs 1 and 4: 8). The upstream and lateral bar areas showed medium to coarse sands (250$1000 \mu \mathrm{m}$; Fig. 5: S9-L), but downstream sites of diagonal and point bars accumulated silt-clay sediments (Fig. 5: S2-L). Thus, the first areas show a similar substrate to the central strip patches, and the second ones to slackwater habitats on the bank strip units. Island formations along the Paraguay main channel were either caused by chute cutoffs resulting in chute-scroll islands, by plant settlement on scroll bars and bar-tail scrolls or by stranded log jams, resulting in lateral islands, or (Drago et al. 2008, this issue Figs. 4: 21, 22, 12: A). Chute islands resulting from chute cutoffs usually were present along the more active reaches, e.g. from Punta Itá Pirú to the Bermejo River mouth (Drago et al. 2008, this issue Figs. 1 and 4: 22).
Scour holes were localized on the outer steep bank of meander bends, at the curved areas of the sinuous reaches, as well as in the channel confluences (Drago et al. 2008, this issue Figs. 4: 23, 8: C,D). Shoals occur in the intervening straight reaches (Drago et al. 2008, this issue Fig. 4: 25). The scour holes in the Lower Paraguay were relatively deep $(20-27 \mathrm{~m})$, with moderate to high current velocity and primarily associated to steep banks. Usually, the substrate showed coarse to medium sands, but sometimes it varied over relatively short distances, presenting sediment with predominance of fine sands and silt-clays. For example, the right bank of main channel at Colonia Herradura was composed in $64 \%$ of fine and very fine sand, $16 \%$ of silt and $20 \%$ of clay (Fig. 5: S6; Drago et al. 2008, this issue Figs. 1: S6, 8:D). The bed was sometimes quite irregular in a transverse section, and large, elongated scour holes exist parallel to the current flow (Drago et al. 2008, this issue Fig. 8A D). Natural steep banks occur associated with the scour holes, on the cut banks sides of the main river bends (Drago et al. 2008, this issue Figs. 4: 24 and 8: A,D), in floodplain channels, and also in some straight reaches. Fallen trees and brushes were common along several steep bank stretches forming logjam patches (Fig. 1.). Besides the asymmetry of the floodplain, the Lower Paraguay shows a major development of high banks on the eastern margin of the valley, because the frequent contact of the river with faults and rock outcrops of Mezosoic age (Comín-Chiaramonti et al. 1992, 1999). Consequently, a poor development of the floodplain occurs along the valley left margin (Drago et al. 2008, this issue Figs. 3, 4 and 5).

\section{Floodplain channel functional set and units}

Floodplain or secondary channels form the drainage system of the floodplain (Fig. 1.; Drago et al. 2008, this issue Figs. 3 and 4: 2). This lotic network shows a low channel density, mainly the ones of permanent flow, very different form the intricate anastomosing-meandering pattern as which developed downriver in the Middle Paraná River floodplain (Drago 1990, Drago et al. 2003, Paira, Drago 2006, 2007). As the main channel, floodplain channels have also developed a complicate ridge and swale topography with a large number of scroll lakes. Some tributaries mainly those of the western margin, flow into these floodplain channels (Drago et al. 2008, this issue Fig. 4: 4 ). The shifting of floodplain channels causes the abandonment of channel reaches, and the development of long and narrow lakes with planforms ranging from straight to meander shapes (Drago et al. 2008, this issuee Figs. 3 and 4). As in the floodplain lakes, the aquatic vegetation is an important 


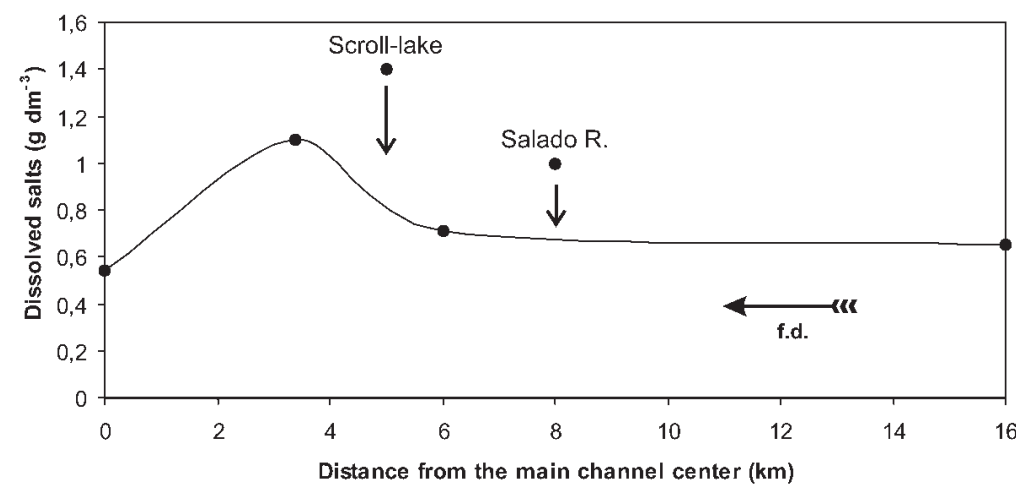

Fig. 6. Salinity variation along the central axis of the Herradura Lake, showing a permanent salt-freshwater ecotone in a sector located from 3 to $6 \mathrm{~km}$ upstream of the connection with the Paraguay River. The ecotone is formed by the input of salt water from a tributary (Salado River), as well as a scroll-lake and a large portion of the wetted perimeter dominated by a salt aquifer. f.d.: flow direction during the Paraguay River floods (see Figs. 1: H1-H5, 5: HL in Drago et al. 2008 this issue).

physical factor in the hydrarch evolution of these lotic waterbodies. The tributary functional unit encompassed the downstream-most reaches of large and small tributary streams that are influenced by backwater flooding from the Paraguay on a regular basis (Fig. 1.; Drago et al. 2008, this issue Figs. 1, 4: 4-5- 6). Within this riverine landscape, we detected three types of hydrological connection degrees with the mainstem as well as with the floodplain waterbodies: 1) tributaries which directly joint with the main channel, as Bermejo, Tebicuary and Neembucú rivers, 2) tributaries that flow some kilometers across the Lower Paraguay floodplain before their inflow directly in the main channel, as the Monte Lindo River, and 3) tributaries flowing into lentic or lotic floodplain water bodies, as Aguapey, Pilagá, San Hilario, Salado and Parahí streams (Figs. 6, 7, 8; Drago et al. 2008, this issue Figs. 1B, 4: 4-5-6). At the river-floodplain scale, this hydrological connectivity operates on longitudinal, lateral, vertical and temporal dimensions. Lateral connectivity links the main channel with floodplain waterbodies, while in the longitudinal connectivity the exchanges can be considered within a continuum between upriver-downriver connection in the parent channel as well as between tributary-main channel and tributary-floodplain waterbodies connections. Vertical exchanges are between the surface and groundwater via infiltration into the alluvial aquifer and the contributions of phreatic water from the valley margins.

The small tributaries of the Lower Paraguay River have moderate to low suspended sediment concentrations (Orfeo 1999; Drago et al. 2008, this issue Fig. 1), ranging from $13 \mathrm{mg} \mathrm{dm}^{-3}$ (Negro River) to $339 \mathrm{mg}$ $\mathrm{dm}^{-3}$ (Monte Lindo River). They show predominantly low-gradient, sandy-silty or clayey-silty channel beds (Drago et al. 2008, this issue Figs. 1, 7: g-j), and relatively slow-flowing during most of the year (Orfeo 1999). During high stages on the Paraguay River, minor tributaries may be dammed and remain sluggish or sometimes flow backwards, even though they are also receiving high discharges from their own catchments. On the contrary, largest tributaries such as Bermejo and Tebicuary rivers, deliver important water and sediment discharges to the Lower Paraguay (Drago et al. 2008, this issue Fig. 1). The Bermejo River strongly changes the sedimentological condition of

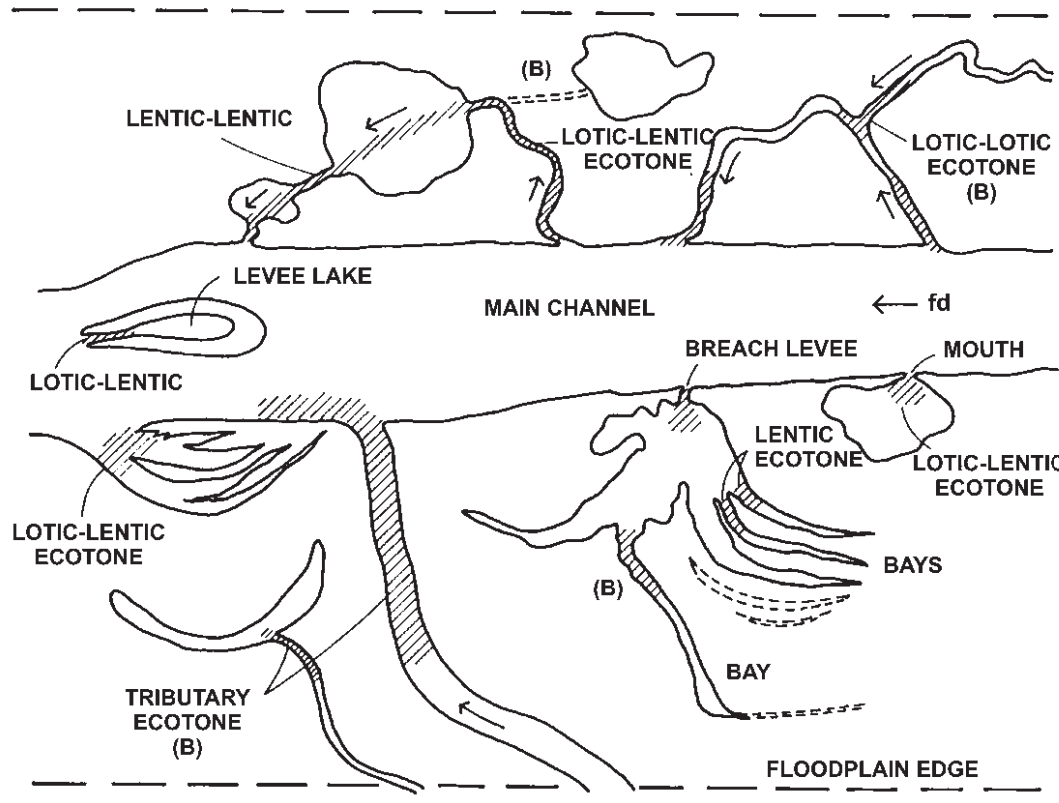

Fig. 7. Main water-water ecotones (striped areas) between lotic and lentic water bodies in the Lower Paraguay river-floodplain. (B): more common connection areas with formation of temporary boundaries. fd: flow direction. (See Figs. 4, 5 in Drago et al. 2008 this issue). 


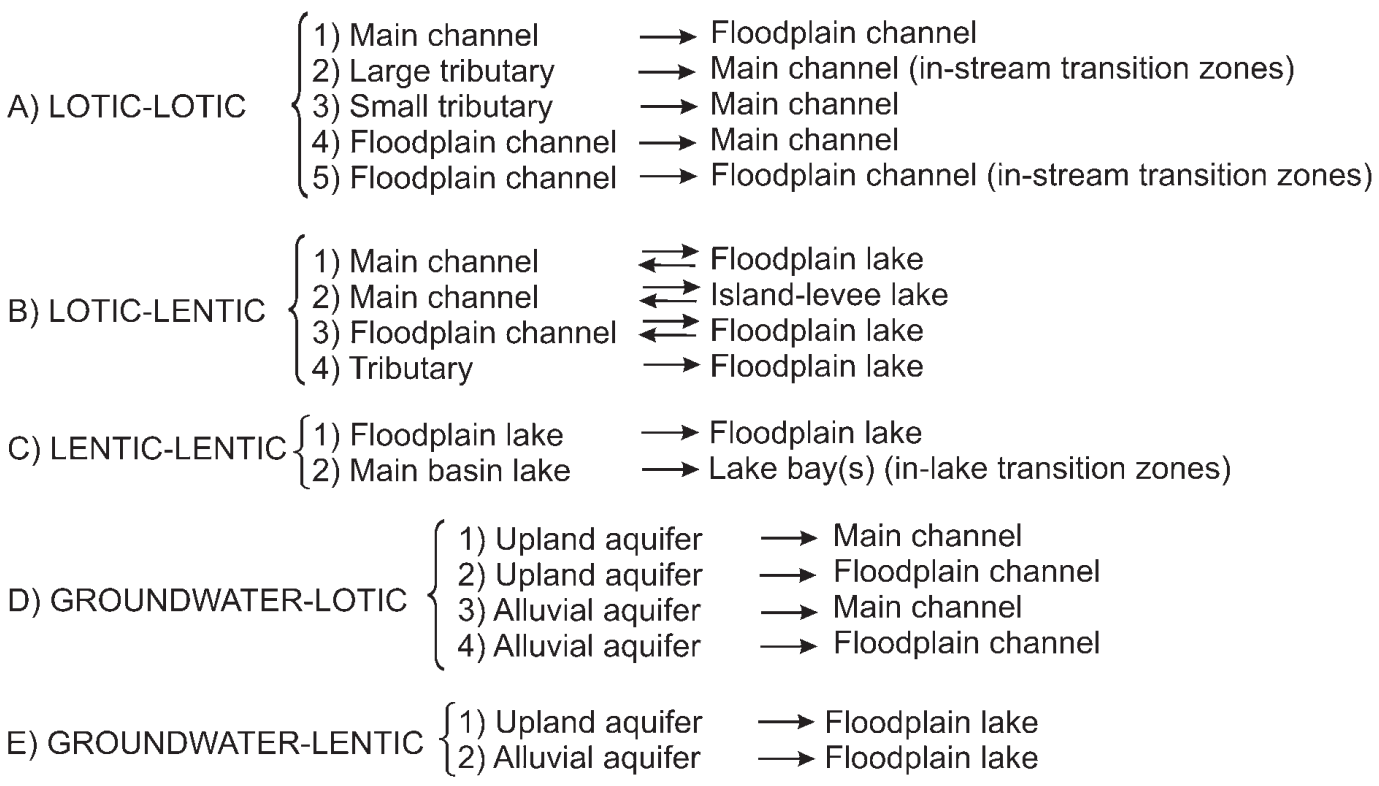

Fig. 8. Main inland water boundaries and ecotones in the lotic and lentic environments of the Lower Paraguay River valley. The arrows are indicating the main flow direction(s).

the Lower Paraguay through its amazing solid discharge. Thus, the mixing zone extended about 500 $\mathrm{km}$ embracing the end reach of the Paraguay River downstream of the Bermejo outlet as well as a large upper segment $(300-400 \mathrm{~km})$ of the Middle Paraná River (Drago, Vassallo 1980; Bonetto, Orfeo 1984). In this way, from the hydrosedimentological point of view, it is possible to detect long and fluctuating physical longitudinal/cross-sectional instream gradients (fluvial ecotones) embracing several hundreds of kilometers, as Lower Bermejo-Lower Paraguay-Middle Paraná fluvial segment ( $>500 \mathrm{~km}$ long). Furthermore, Tebicuary and Bermejo rivers have also fringing floodplains, which form an "alluvial terrains continuum" from the Paraguay floodplain to upstream of both tributaries. Therefore, both rivers show important riverfloodplain ecotones where the Paraguay River water periodically also floods the lotic and lentic water bodies of those large tributaries.

Mesohabitats as scour holes and shoal areas are formed in the river bends as well as at the mouth of some largest tributaries (Fig. 1.). We detected deep scour holes of $28 \mathrm{~m}$ and $22 \mathrm{~m}$ depth at the bends of Humaitá (Paraguay, rkm 1288) and Curupayti (Paraguay, rkm 1273), respectively. These scour holes have been also described for the confluences of large sand-bedded rivers (Best, Ashworth 1997, Paola 1997). The shoal areas were formed by accumulations of sediment carried by tributaries and the main channel or by rock outcrops. The alluvial shoals usually showed a higher heterogeneity in their grain size composition than those, of the main channel bars, due to the mixing of sediments from the forming rivers. Generally, they were located slightly downriver of the tributary mouths. Rock outcrop shoals were common between Asunción city and Punta Itá Pirú, being mainly detected on the left river bank strip.

\section{Floodplain lake functional set}

Floodplain lakes of the Lower Paraguay floodplain can be divided in the following shape types: 1) round-oval lakes, 2) elongated or channel-shaped lakes, and 3) irregular lakes (Paira, Drago 2006, 2007). They may range in planform shape from very irregular basins formed by the annexation of several scroll lakes or highly bended surfaces (oxbow lakes, often multiloop meanders) to simple elongated and round forms (Drago et al. 2008, this issue Figs. 4: 7-8-10-15, 5: HL, 11A-B: 5). This basin shape diversity is strongly linked with the degree of patches heterogeneity, i.e., the major irregularity in the lake basins usually is associated with a major meso- and microhabitat variety (Fig. 9). Major oxbows - the former main river reaches, were the largest lakes of the floodplain, ranging from 0.2 ha to $>600$ ha, and exceeding $13 \mathrm{~km}$ long and $700 \mathrm{~m}$ wide. Due to their origin and the low infilling rates, they showed a similar morphology to the present main channel, were permanent and deeper (often $>5 \mathrm{~m}$ ) than others floodplain lakes (Drago et al. 2008, this issue Figs. 1: H1-H5, 4: 7, 5: HL).

Lentic waterbodies may be supplied by water from different origins: 1) surficial river water as flow pulses (sensu Tockner et al. 2000) through channeled direct and indirect connections, and overflows during floods, 2) groundwater seepage 
from alluvial aquifers and channel levee filtration, 3 ) groundwater drainage from aquifers located on the valley margins, and 4) surface river water supplied by direct flow or by overflow from tributaries. Therefore, even within the same floodplain sector, alluvial lakes may be feeding by waters differing in their physical and chemical conditions (Drago et al. 2008, this issue Fig. 4: 2, 7, 16). Figure 10 illustrates the main surficial flow pathways of the floodplain hydrological connectivity related with the different river water stages and the intensity in the degree of connection during rising and falling water phases.

As a consequence of saline water contribution from the western tributaries with a range from 1 to $15 \mathrm{~g} \mathrm{dm}^{-3}$, several lakes increased markedly its salinity reaching up to $1 \mathrm{~g} \mathrm{dm}^{-3}$. However, neighbouring lakes withouth saline tributaries depictes remarkable lower salinities of around $200 \mathrm{mg}$ $\mathrm{dm}^{-3}$. Large oxbows, as Herradura Lake (Drago et al. 2008, this issue Fig. 5: HL) increased markedly its salinity (from $0.6 \mathrm{~g} \mathrm{dm}^{-3}$ to $1.1 \mathrm{mg} \mathrm{dm}^{-3}$ ), towards the sites with the co-occurrence of surface and ground-water supplies of different origin and salinity (Fig. 6). In this case, the increasing of salinity was detected on the right shoreline and parts of the lake center, forming a lateral in-lake ecotone during mean and low river levels.

Therefore, this kind of water bodies usually show a composite hydrological connectivity and feeding type: a) salt water from tributary stream(s), b) old local salt- or freshwater supply from the floodplain lake-channel network, and c) regional fresh river water from the main channel. These lentic environments display sometimes strong lateral and longitudinal physical and chemical gradients, even during inundation phases (Drago et al. 2003; Drago 2007).
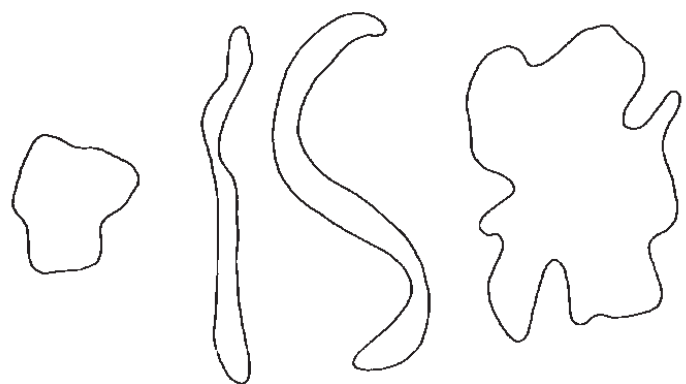

BASIN SHAPE TYPES
Some tributaries, as Bermejo River, strongly affect the water conditions of the Paraguay floodplain lakes, for example, decreasing dramatically their water transparencies during the Bermejo floods. Thus, lentic waterbodies receiving high turbid tributary waters decrease more than $50 \%$ in its transparency, and some lake bottom areas notably increased their silt and clay percentages, from $30-40 \%$ to $80-99 \%$. In fact, it is possible to detect a strong relationship among the connectivity degree and the bottom lake sediment characteristics (Fig. 11). Thus, a lesser connectivity together with a longer residence time indicates a major concentration of silt and clay on the lake bottoms (Figs. 5: H1-H2-H3-H4, 11). Furthermore, lake basins colonized by dense stands of helophytes and hydrophytes, contain also important amounts of organic matter in their bottom sediments $(\geqq 10$ $\%)$. Small oxbow lakes are abandoned meanders of both floodplain channels and tributaries entering to the alluvial valley mainly from the western margin (Drago et al. 2008, this issue Fig. 4: 12-26). Some tributaries as Bermejo and Tebicuary rivers cross the floodplain building also oxbow lakes, which are also flooded by the Paraguay waters, being clear examples of astatic waterbodies. Minor tributaries, as the streams Negro, Inglés, Monte Lindo, Pilagá and Salado among others, build similar riverscapes (Drago et al. 2008, this issue Figs. 1B, 4: 4-26).

Scroll lakes are extremely common mesohabitats in the Lower Paraguay floodplain (Drago et al. 2008, this issue Figs. 4: 15-16-17, 5). During overbank phases, some scroll lakes near to the main channel lose their lentic conditions. Even at these times current velocities were generally too slow to scour the bed $\left(\leq 0.5 \mathrm{~m} \mathrm{~s}^{-1}\right)$ which usually contained more than $80 \%$ of silt-clayed or clay-silted substrates, often with a thick layer of organic detritus (Fig. 5: H1-H4). The new series of scroll lakes are usually directly connected at their downstream ends with the active channels, showing different substrate conditions due to the flood-drought and flow pulses (Fig. 5: DL; Drago et al. 2008, this issue Fig. 4: 16-17).

The lakes near to the active channels, mainly those with a direct connection (a mouth or a channel crevasse), will received larger amounts of river sand. On the contrary, lakes located away from active channels or completely isolated will received major amounts of fine suspended sediment.
Fig. 9. Hypothesized patches heterogeneity gradient along an increasing of lake shape complexity. 


\section{FLOODPLAIN HYDROLOGICAL CONNECTIVITY (MAIN FLOW PATHWAYS)}

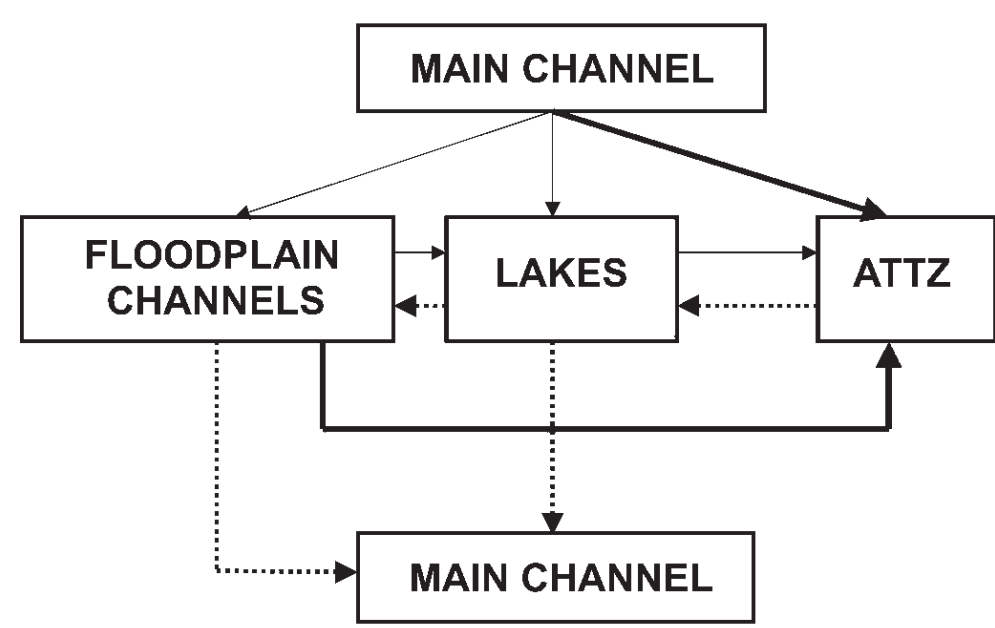

bottom (Figs. 5:H5, 11), whereas in the opposite upstream point the substrate was predominantly clayey-silt (Figs. 5:H, 11). Dead-arms, permanently connected at their downriver end, presents also the highest amount of sand in their bottoms, mainly near to the connection mouth (Fig. 5:DL). The same feature is also detected in the recent scroll lakes, were the very fine sand fraction in these sandy lake bottoms is always predominant. In the abandoned reaches near of the active channels, the highest floods create tracts of sandy substrates within the still-water biotopes which increase the habitat diversity and species richness (Ezcurra de Drago 1980; Ezcurra de Drago et al. 2004, 2007).

Within a continuum from directly connected lakes to those completely isolated, there is a diverse structure and cover degree of the aquatic and palustrine vegetation and riparian forest. The increasing of this autogenic factor drives the sediment amount and size grain carthe Lower Paraguay river-floodplain hydrosystem.

The largest oxbow lakes, for example, usually present highest concentrations of sand at their downstream ends close to the water courses. The largest concentrations of silt and clay are detected progressively away from the active channels (Figs. 5:H1, H2, H3, H4, 11). However, this typical sediment size distribution is sometimes altered by the contributions of sandy sediment at the mouth of tributaries and floodplain channels (Fig. 5: H5). Some lakes are sharply disconnected from the channels due to strongly local aggradation processes, being the alluvial plugs rapidly overgrown by dense stands of alder (Tessaria integrifolia) and willow (Salix humboldtiana), thus accelerating the disconnection and terrestrialization processes. In summary, within an oxbow lake connected with the river in their downstream end (a "parapotamon", sensu Ward, Stanford 1995), we detected a predominance of sand on the

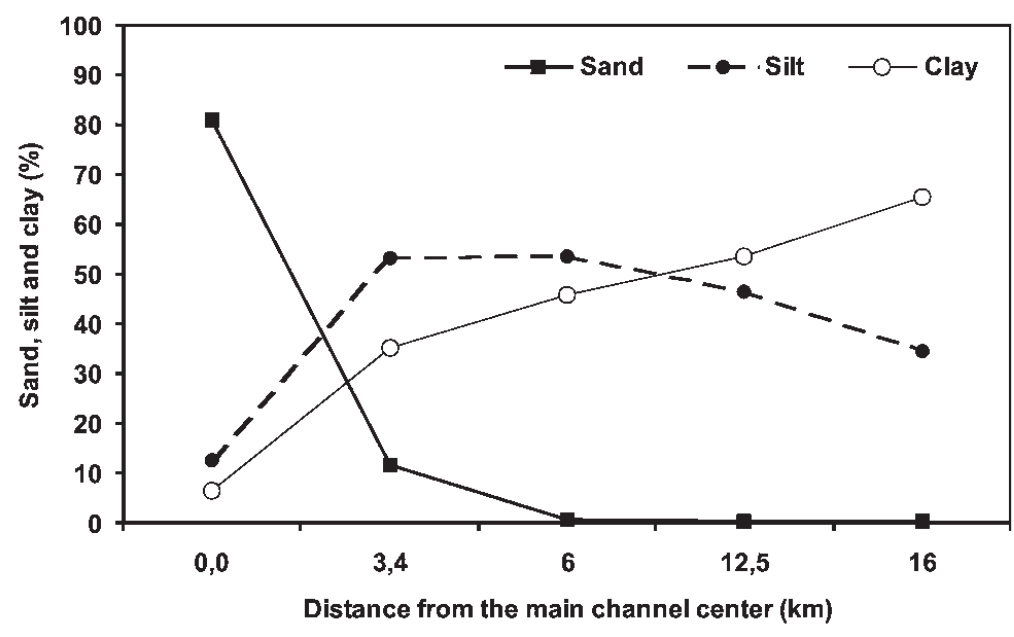

Fig. 11. Changes of sand, silt and clay percentages of the bottom sediments at the Herradura Lake in relation to the distance from the connection point with the Paraguay River (see Figs. 1: H1-H5, 5: HL in Drago et al. 2008). 
in the Lower Paraguay floodplain (Drago et al. 2008, this issue Fig. 4: 8-15-16). The resulting scroll-bar complexes show arcs of two distinct sizes, outer arcs on the scale of the main channel and inner arcs on the scale of the floodplain channels (Drago et al. 2008, this issue Figs. 4: 15, 5). The evolution of the ridge-swale-floodplain topography, originate lakes with an irregular shape, and the erosion of the ridges enlarge the lake surfaces by the annexation of other scroll swale sets (Drago et al. 2008, this issue Fig. 4: 8-16). The small islands commonly observed in this type of water body are remnants of the old ridges (Drago et al. 2008, this issue Fig. 4: 9). On the active border of the floodplain-main channel, diagonal bars build also series of narrow lakes with their downriver ends open to the main channel (Drago et al. 2008, this issue Fig. 4: 17), and an irregular basin originates when the downriver connection is closed by deposition (Drago et al. 2008, this issue Fig. 4: 16). Another type within the irregular basins are the 'contorted' lakes, which formed when two opposite adjacent scroll series are annexed (Drago et al. 2008, this issue Fig. 4: 27). Several irregularscrolled lakes are directly connected with large and small oxbows, forming large lentic environments which including different mesohabitats as open water, palustrine vegetation areas, free-floating or rooted macrophytes stands, etc. (Fig. 1.; Drago et al. 2008, this issue Fig. 4: 7-8). In some floodplain areas far away of the parent channel, the old meander scroll surface is blurred and several round-elliptical lakes cover the floodplain (Paira, Drago 2007; Drago et al. 2008, this issue Fig. 4: 10). Usually, they are covered by hydrophytes and surrounded by swampy areas (Drago et al. 2008, this issue Fig. 4: 10-11), having also deep, muddy substrates with an abundance of coarse organic debris (usually leaves and sticks), and depths typically less than $2 \mathrm{~m}$. The largest areas with rounded waterbodies are mainly developed at the surroundings of the Punta Itá Pirú floodplain-section and to the north of the Bermejo River mouth (Drago et al. 2008, this issue Figs. 1, 4: 10-11, 5a).

Shape and location of the floodplain lakes in relation to the active fluvial axes are important morphological conditions for the limnological response to the flood-pulse action (e.g., producing an environmental heterogeneity at small scale). Channelshaped lakes nearest and parallelly orientated to the active channels has larger possibilities for striking physical changes during the highest floods, whereas lakes located transversally to the active channels, show lesser physical changes by the protection of levees with gallery forests (Drago et al. 2003; Drago 2007; Paira and Drago 2006, 2007). Therefore, the nature and intensity of the hydrological connectivity in the lentic water bodies depends on their morphological structure and their relative position into the floodplain drainage network.
We differentiated the following hydro-functional lentic units (Fig. 1.): a) Directly connected floodplain lakes: Water bodies with a direct and short connection to the main channel or floodplain channels through a mouth, an erosion breach (crevasse) or a floodplain channel with no more than a $1 \mathrm{~km}$ length (Drago et al. 2008, this issue Figs. 4: 16-17, 5, 11). During the inundation phase, they may experience lotic conditions. Several current velocity gradients were detected within large irregular lakes, while small channel-shaped basins presented a sharp increase in water flow in its entire surface (from 0 to $0.5 \mathrm{~m} \mathrm{~s}^{-1}$ at the centre of a small elongated lake; February 2004). Some waterbodies were permanently connected with the main or floodplain channels during several years. However, this highest level of connectivity may be interrupted by severe droughts phases occurred during particular climatic conditions such as the ENSO events (e.g. La Niña 1999-2000). These kind of lakes exhibited a high hydrological connectivity and a low residence time of less than six months in average (Drago et al. 2008, this issue Table I, Figs. 4, 5). b) Indirectly connected floodplain lakes: These water bodies are fed by the channel-lake network of the floodplain. They may be connected by a long single floodplain channel or a channel with interspersed lakes (Drago et al. 2008, this issue Figs. 4: 7-8-15, 5: HL, 11, 12). In the Paraguay floodplain, these connection pathways may reach up to $8 \mathrm{~km}$ in length. Therefore, the floodwater flowing into these lentic environments during the channeled-rising and overspill water phases can be sometimes distinctly different in their physical and chemical characteristics, e.g. after flowing $4 \mathrm{~km}$ through a lake the suspended sediment concentration of the Paraguay flood water decreased more than $80 \%$ (Drago et al. 2008, this issue Fig. 12B: lake 1; February 2004). The indirectly connected lakes show an intermediate hydrological connectivity as well as an intermediate residence time, about less than one year on average (Drago et al. 2008, this issue Table I, Figs. 4: 7-12-15, 5: HL). c) Isolated floodplain lakes: Water bodies without tributaries or drainage channels (Drago et al. 2008, this issue Figs. 4: 10, 5: a). They only receive floodwater through overbank flow and to a lesser degree from rain or groundwater seepage. The floodwaters reaching these lakes are strongly filtered due to the trap effect of the floodplain roughness (relief, vegetation, other lentic waterbodies), thus resulting in the environments with the lowest infilling rates on the floodplain (Drago et al. 2003, Drago 2007, Paira and Drago, 2006, 2007). However, they are surrounded by swampy areas and covered totally or partially by aquatic and palustrine vegetation which promote large detritus accumulations and the deposition of fine inorganic sediment, which accelerates the slower terrestrialization process in 
these kind of lakes. These water bodies display a low hydrological connectivity, long residence times ( $>$ one year on average) and consequently, they have the oldest local or residual water of the floodplain, (Drago et al. 2008, this issue Table I; Figs. 5: a, 11: 5). These types of lakes are located in the former areas of the alluvial landscape and are usually associated with d) marshes and e) swamps. Marshes are temporary water bodies formed in very shallow depressions without welldefined edges, originating through uneven aggradation of alluvial materials on the floodplain surface. The residence time of floodwater or rainwater is short. Swamps are the terminal phase of the terrestralization process of floodplain lakes, with their surfaces predominantly covered by Echinochloa polystachya, Paspalum repens, Polygonum spp., Panicum elephantipes, Ludwigia peploides, and Hydrocotyle ranunculoides. On their margins are common dense stands of Typha spp., Scirpus californicus, Solanum glaucophyllum and Panicum prionitis, whereas the higher sandy areas are mainly overgrowed by patches of Tessaria integrifolia (Drago et al. 2008, this issue Figs. 4: 11, 5: a).

\section{Lotic and lentic boundaries and eco- tones}

Lotic and lentic boundaries and ecotones are regarded herein as differing in gradient intensity, with the former showing abrupt discontinuities, whereas the later involve more gradual environmental transitions between adjacent inland water systems (Ward 1998; Ward, Wiens 2001). Within these transition zones we encompassed the riverfloodplain lotic-lotic, lotic-lentic, lentic-lentic as well as the upland lotic (tributaries) and groundwater linkages (Figs. 4, 6, 8, 11). We would stress that because the strong differences in salinity that may be find within the same fluvial hydrosystem, it would be necessary to use the term "inland-water" ecotones instead of "freshwater-freshwater" ecotones. For example, several streams of the Paraná River basin show salinities largely over 15 $\mathrm{g} \mathrm{dm}^{-3}$, which allow the development of salinity boundaries and ecotones (Drago, Paira 1997). Boundaries and ecotones operate as controls of the movement of water, sediment and organic matter throughout the river-floodplain complex, besides showing a rich variety of flora and fauna assemblages (Holland 1988, 1995, 1996, Risser 1995).

Longitudinal transition zones (boundaries and ecotones) include the up- and downstream reaches of the main river and tributary confluences, as well as the confluences and mixing reaches along the major and minor rivers and streams of a drainage basin. Furthermore, the different segments within allochtonous streams are considered as forming physical and chemical boundaries and ecotones. In the Lower Paraguay basin, the Pilcomayo and Bermejo rivers are good examples of like some environmental variables deeply change their longitudinal environmental characteristics. For example, the Pilcomayo River strongly increased the salinity from less than 0.4 $\mathrm{g} \mathrm{dm}^{-3}$ in the upper basin to over $30 \mathrm{~g} \mathrm{dm}^{-3}$ in its middle allochtonous-intermittent segment. This fact develops a boundary, which originates a chemical barrier for several freshwater species, avoiding the upstream invasion of the exotic species as the golden mussel Limnoperna fortunei from the Lower Paraguay River (Drago et al. 2006). Furthermore, the allochtonous condition of the Pilcomayo River creates severe droughts along the middle and lower segments of the Pilcomayo River, enhancing the boundary effects. On the other hand, the Bermejo River also shows a physical barrier on some freshwater species, as the golden mussel L. fortunei, due to its huge sediment discharge (Drago et al. 2006). This high amount of suspended and bed sediment creates a longitudinal-physical boundary at the confluence with the Paraguay River. As lateral water boundaries and ecotones we included the lotic-lotic, lotic-lentic and lentic-lentic transition zones which develop within the large scale ecotone: the fringing floodplain. Vertical boundaries and ecotones encompass the hyporheic habitat, i.e., the groundwater connections between floodplain lotic and lentic water bodies, and the upland aquifer-river valley connections.

Longitudinal and lateral ecotones in large rivers may vary in size from meters to hundreds of kilometers, i.e., from substratum patches in the main and floodplain channels to the long mixing zones (lotic-lotic ecotones) downstream of large tributary confluences. The predominant gradients in the longitudinal as well as in the lateral dimension are slope, current, suspended sediments, bed sediments, salinity of surficial and groundwater, dissolved oxygen, chemistry, and organic resources.

\section{Longitudinal dimension}

The Lower Paraguay-Middle Paraná axis presents the largest longitudinal lotic-lotic ecotone of the Río de la Plata Basin, which encompassed $500 \mathrm{~km}$ from the Lower Paraguay end river reaches to the upper segment of the Middle Paraná River (from $26^{\circ} 50^{\prime} \mathrm{S}$ to $30^{\circ} 00^{\prime} \mathrm{S}$ ). Thus, at the confluence of the Bermejo and Paraguay rivers a boundary (sensu Ward 1998) is formed, and downstream a longitudinal mixing zone or ecotone occurrs, which extends to the joining with Middle Paraná River segment (Fig. 8.). From this confluence a cross-sectional physical boundary it is formed, where the higher sediment-lad- 
den water of the Paraguay River and the lesser turbid Paraná water are completely mixing then to flow apart near $300-400 \mathrm{~km}$ downstream (Drago, Vassallo 1980, Zalocar de Domitrovic et al. 2007). According the water stages of Paraguay, Bermejo and Paraná rivers, these "zones of mixing" (usage Benda et al. 2004) strongly fluctuated in their longitudinal and lateral in-stream dimensions. The mixing effects downstream of the Paraguay-Bermejo confluence, including a steeper channel gradient and a higher frequency and magnitude of disturbance, arise from the abrupt introduction of sediment and wood from the Bermejo River. During the high levels of the Paraguay and Bermejo rivers, their very turbid waters flow on the right bank occupying a belt which fluctuates between $0.4 \mathrm{~km}$ and $2 \mathrm{~km}$ in width, whereas the Paraná water flows on the left bank and most of the channel center. This fact is due both to the discharge relationships between the Paraná and Paraguay rivers $(4: 1)$ and the channel geometry of the Paraná main stem, which even though presents a mean width of $2.83 \mathrm{~km}$ between Corrientes and Esquina (Argentina), its thalweg is usually located on the left bank. Therefore, the large discharge of the Upper Paraná is routed through the left bank, thus enhancing the lateral as well as the longitudinal dimensions of this fluctuating transition zone. Conditions of a channel cross-sectional and longitudinal boundary for the phytoplankton were found by Zalocar de Domitrovic (2002) and Zalocar de Domitrovic et al. (2007). Thus, in the Lower Paraguay upstream and donwstream of the Bermejo River mouth this author sampled 248 and 123 species respectively. At the confluence Paraguay and Paraná, the last river supplied 380 species which number is maintained on the left bank (Paraná water), whereas on the opposite right bank the species number are similar to that of the reach end of the Lower Paraguay (Zalocar de Domitrovic 2002). This variation in the abundance and composition of the phytoplankton is produced by the high turbidity of the Paraguay water, which forms a "phytoplanktonic cross-sectional boundary" of more than $300 \mathrm{~km}$ along the Middle Paraná River.

The confluence effect on the benthic community were demonstrated by Ezcurra de Drago et al. (2004) through data obtained along the "interference" and "mixing" zones (usage Benda et al. 2004), i. e., upstream and downstream of Bermejo outlet. Thus, upstream of the Bermejo River mouth, the bed central strip of the Paraguay River has a specific richness of 12 and density above 4000 ind. $\mathrm{m}^{-2}$, whereas downstream of that confluence, the river shows a specific richness of 3 , and a density of 51 ind. $\mathrm{m}^{-2}$ (Ezcurra de Drago et al. 2004, Ezcurra de Drago, unpubl.). Meanwhile, the Bermejo River presents a specific richness of 3 and a density of 30 ind. $\mathrm{m}^{-2}$, as a result of the hard environmental conditions of this river, as its high concentration of suspended sediments (an average of $6.5 \mathrm{~g} \mathrm{dm}^{-3}$ and a maximum of $15 \mathrm{~g} \mathrm{dm}^{-3}$; Drago, Amsler 1988; Amsler, Drago in press). On the contrary, fishes as Prochilodus lineatus ("sábalo") and Salminus brasiliensis ("dorado") migrate $700 \mathrm{~km}$ and 250 $\mathrm{km}$ (or more) respectively upstream of the Bermejo River from the Paraguay River, and also more than $500 \mathrm{~km}$ downstream of the Bermejo mouth through the Lower Paraguay and Middle Paraná river ecotones (Bonetto et al. 1971).

In summary, in the longitudinal dimension, the Lower Paraguay-Middle Paraná axis depicts two large ecological transition zones along the following mixing segments: a) a permanent longitudinal-fluctuating ecotone in the $80 \mathrm{~km}$ end reach of the Paraguay River, downstream of the Bermejo mouth, and b) a permanent fluctuating longitudinal/transversal ecotone along near 300$400 \mathrm{~km}$ downstream of the Paraná-Paraguay confluence (Drago, Vassallo 1980; see Fig. 5.29 in Bridge 2003; Zalocar de Domitrovic 2002; Zalocar de Domitrovic et al. 2007). The characteristic of this second ecotone is that to maintain a markedly separation of the Paraguay-Bermejo water on the right channel margin, and the Paraná water flowing on the left and center of the channel margin, which flow parallelly for some hundreds of river kilometers. This "assymmetric flow" forms a boundary for the phytoplankton community, according the data obtained by Zalocar de Domitrovic (2002). Thus, the longitudinal as well as the transversal ecotonal areas of the Middle Paraná main channel are driven by the the high suspended sediment discharge supplied by the Bermejo River, the major sediment contributor in the Paraná drainage basin.

\section{Lateral dimension}

Several lateral boundaries and ecotones were distinguished (Fig. 8.): a) large tributarymain channel (lotic-lotic), as the boundary at the joining of Paraguay and Bermejo rivers. This boundary arise as a physical barrier for the benthic species inhabiting the Paraguay River, such as the invasive golden mussel Limnoperna fortunei (Bivalvia, Mytilidae) in the Pilcomayo and Bermejo rivers (Drago et al. 2006); b) minor tributary-main channel (lotic-lotic), e.g., small tributaries flowing into the main channel, as Inglés, Parahi, Ñeembucú, and de Oro streams among others. These tributaries may present boundaries and ecotones, which are spatially driven by the main river floods through upstream backwaters, and in a lesser degree by their proper tributary floods. Moreover, some streams flowing from the Chaco-Pampa plain may show salin- 
ity boundaries and ecotones, due to the high concentrations of dissolved solids ranging from 5 to $25 \mathrm{~g} \mathrm{dm}^{-3}$ in average (Lancelle et al. 1986; Drago et al. 2006). The edges of these boundaries and ecotones are highly mobile because their up- and downstream water shiftings; c) minor tributary-floodplain lake (lotic-lentic), as that formed when a upland small stream flows directly to a lake. These condition originated ecotones, as that formed when the salt water of the Salado River $\left(1 \mathrm{~g} \mathrm{dm}^{-3}\right)$ flows into the Herradura Lake $\left(0.6 \mathrm{~g} \mathrm{dm}^{-3}\right)$. In the Herradura Lake, environmental conditions derived from suspended sediments and salt water flowing from tributaries and aquifer, as well as to the substrate changes, creating lateral and longitudinal in-lake transition zones (Figs. 6, 11). Sometimes, there is a sucession in the gradient conditions, from abrupt instream-inlake changes (boundary) to a more gradual inlake transitions (lacustrine ecotone); d) major floodplain channel-minor floodplain channel (lotic-lotic), formed at the confluence or divergence of floodplain channels during the receding of flood phase. At that moment the major stream leaves to inject water to the minor stream, and at the same time, to dam it. Thus, the minor stream ceases its flow and begins to develop strong lentic characteristics, whereas the major stream maintains its lotic conditions, forming a small/transient boundary; e) transient inlake ecotones (lotic-lentic), formed during the midwater to bankfull river stage, when the flow pulses inject regional water to the directly connected lakes (Drago et al. 2003; Drago 2007). These types of transition zones are very common in the irregular lakes (Fig. 7), where the long and narrow bays maintain the local water characteristics, even during the overbank floods; f) temporary mixing zones, showing sometimes abrupt borders are formed on the water bodies and on the aquatic-terrestrial transition zones (ATTZ, Junk et al. 1989) mainly on the older floodplain areas, which can be maintained during the flood phases. These are sectors of mixing of river and local water that were defined as the "perihreic zones" (Mertes 1997), being typical features in the large river floodplains. During floods, the invasion of river water across the surface of floodplain may be resisted by water already present on the floodplain due to groundwater, direct precipitation, flooding of tributaries, and antecedent water from preceding floods. Because of that, large patches of local water may be surrounded by river water and never be completely absorbed, thus producing a mixing zone that conforms approximately to the shape of the ATTZ topography driving the location of the ponding. In the Lower Paraguay floodplain these un-mixed zones are very common in isolated lakes, in long and narrow large lake bays and on the largest depressions containing swamps (Drago et al. 2003). Aquatic and palustrine vegetation, as well as dense forests are also main factors in the formation of the perhireic zones because to their sediment trap effect and the reduction of the water velocity (Drago et al. 2003; Drago 2007). This regional-local areas of mixing and its relationship with the freshwater communities were not yet investigated.

\section{Vertical dimension}

Major exchanges of surficial water and groundwaters at channels-lakes-upland complex are associated with alluvial and upland aquifers (Figs. 1, 7,). No data yet exist about the fauna inhabiting the hypogean realm in the large South American riverfloodplains. In the Lower Paraguay floodplain, the following bounding units for the major ecotones were distinguished: 1) upland aquifer-main channel, 2) aquifer-floodplain channel, 3) aquifer-lake, 4) river-levee-lake. The last hypohreic corridor is produced during the increasing of the river level up to the bankfull stage, and then during the flood recession until the river level falls below the mean stage. In this process, the flow pulses originate an increasing of the isolated lake level by the injection of river water both by filtration through the levee and via the aquifer. If the aquifer has salt water, the changes in salinity can be detected in the lake bottom water (Drago et al. 2003; Drago 2007). The aquifer-lake transition represents vertical ecotones between uplands or alluvial aquifers with any lentic waterbody on the floodplain.

\section{Conclusions}

- The meandering functional sector of the Lower Paraguay contains five functional sets, which encompass twenty one functional units and sixty one aquatic mesohabitats.

- The origin of the floodplain waterbodies, their stage of evolution and the connectivity degree generated a discontinuous gradient of connectivity both in space and time.

- The lateral and longitudinal fluvial/lacustrine connections within the floodplain (main channel $\rightarrow$ floodplain channel $\rightarrow$ main channel), as well as the lotic-lentic and lentic-lentic connections (channel $\leftrightarrow$ lake $\leftrightarrow$ lake) depends on the strength, duration and timing of the water linkage. - Hydraulic connectivity is high in a floodplain belt on the main river of $7 \mathrm{~km}$ width in average, and rapidly declines to the older floodplain areas located $12 \mathrm{~km}$ in average from the parent channel.

- The characteristic floodplain hydrographical pattern is the low density of the oxbows and the deranged drainage in the former floodplain sectors. 
- Differences in origin and connection degree of the lentic environments, the greater or lesser distance to the active channels, and the physical and biological evolution, are the main factors affecting the bottom sediments distribution in the same water body and in between lakes.

- Eight lateral transition zones were distinguished: 1) Large tributary-main channel (lotic-lotic boundary), 2) Small tributary-main channel (lotic-lotic, 3) Small tributary-floodplain lake (lotic-lentic), 4) Large floodplain channel-small floodplain channel (lotic-lotic), 5) Transient inlake ecotones (lotic-lentic), 6) Partial mixing zones (lotic-lentic), showing sometimes sharp borders or boundaries ("perirheic zones).

- The following bounding units for the major vertical ecotones were distinguished: 1) Upland aquifer-main channel; 2) Alluvial aquifer-river bed; 3) Upland aquifer-floodplain lake; 4) Alluvial aquifer-bottom lake; and 5) Riverlevee-lake.

- The hydrological connectivity, the different types of ecotones and their dynamics, are the primary determinants of the habitat heterogeneity in the near-pristine Lower Paraguay River, thus maintaining its eco-functional integrity.

\section{Acknowledgements}

This article results from the cooperation between the National Institute of Limnology (INALI-CONICET), Santo Tomé (Santa Fe), Argentina, and the Tropical Ecology Work Group of the Max-Planck-Institute for Limnology (MPIL), Plon, Germany. Financial and technical support has been given by the PROALAR Program of the Deutsche Akademische Austauschdients (DAAD, Reg. N D99 15373) and the Argentinian National Agency of Scientific and Technical Promotion (SECyT Reg. N 99-00010). Special thanks are given to the technicians Lionel Mehaudy, Ramón Regner, and Eduardo Lordi, INALI, for their unwearied help with field work.

\section{References}

Amoros, C., Roux A.L., Reygrobellet J.L, Bravard J.P., Pautou G. 1987. A method for applied ecological studies of fluvial hydrosystems. Reg. Rivers: Res. Mgmt. 1, 17-36.

Amoros, C., Roux A.L. 1988. Interaction between water bodies within the floodplains of large rivers: function and development of connectivity. In: Schreiber, K. F. [Ed] Connectivity in Landscape Ecology. Münstersche Geogr. Arb. 29, 125-130.

Amoros, C., Bornette G. 2002. Connectivity and biocomplexity in waterbodies of riverine floodplains. Freswat. Biol. 47, 761-776.
Amsler, M.A., Drago E.C.A review of the suspended sediment budget at the confluence of the Paraná and Paraguay Rivers. Hydrological Processes (in press).

Arscott, D.B., Tockner, K., Ward, J.V. 2000. Aquatic habitat diversity along the corridor of an alpine floodplain river Fiume Tagliamento, Italy. Arch. Hydrobiol. 149, 679-704.

Baker, J.A., Killgore, K.J., Kasul, R.L. 1991. Aquatic habitats and fish communities in the Lower Mississippi River. Aquatic Sciences 3, 313-356.

Benda, L., Poof, L.N., Miller, D., Dunne, T., Reeeves, G., Pess, G., Pollock, M. 2004. The network hypothesis: How channel networks structure riverine habitats. BioScience 54, 413-427.

Best, J.L., Ashworth, P.J. 1997. Scour in large braided rivers and the recognition of sequence stratrigraphic boundaries. Nature 387, 275-277.

Bonetto, A., Pignalberi, C., Cordiviola de Yuan E., Oliveros, O. 1971. Informaciones complementarias sobre migraciones de peces en la Cuenca del Plata. [Complementary data on fish migrations in La Plata Basin] Physis 30, 505-520.

Bonetto, A., Orfeo, O. 1984. Caracteres sedimentológicos de la carga en suspensión del río Paraná entre confluencia y Esquina (Prov. de Corrientes) [Sedimentological characteristics of the suspended load of the Paraná River between confluencia and Esquina (Corrientes Province).] Revista de la Asociación Argentina de Mineralogía, Petrología y Sedimentología 15, 51-61.

Bridge, J.S. 2003. Rivers and Floodplains. Forms, Processes, and Sedimentary Record. Blackwell Publishing.

Comín-Chiaramonti, P., Gomes, C., Petrini, R., De Min, A., Velazquez, V., Orué, D. 1992. A new area of alkaline rocks in eastern Paraguay. Rev. Brasilerira de Geociencias 22, 500-506.

Comín-Chiaramonti, P., Cundari, A., Degraff, J.M., Gomes, C., Piccirillo, E. 1999. Early cretaceous-tertiary magmatism in eastern Paraguay (Western Paraná Basin): geological, geophysical and geochemical relationships. J. Geodynamics 28, 375-391.

Drago, E.C. 1980. Aspectos limnológicos de ambientes próximos a la ciudad de Santa Fe (Paraná Medio): Comportamiento hidrológico y sólidos suspendidos. [Limnological aspects of environments near Santa Fe city (Middle Paraná River): Hydrological behaviour and suspended solids.] Ecología (Argentina) 5, 31-48.

Drago, E.C. 1981. Grados de conexión y fases hidrológicas en ambientes leníticos de la llanura aluvial del Río Paraná (Argentina). [Connection degrees and hydrological phases in lentic environments of the Paraná river floodplain (Argentina)] Ecología (Argentina) 6, 27-33.

Drago, E.C. 1984. Estudios limnológicos en una sección transversal del tramo medio del río Paraná. VI: Temperatura del agua. [Limnological studies in a cross- 
section of the middle reach of the Paraná River, VI: Water temperature.] Rev. Asoc.Cienc. Nat. Litoral 15, 79-82.

Drago, E.C. 1989. Morphological and hydrological characteristics of the floodplain ponds of the Middle Paraná River (Argentina). Rev. Hydrobiol. trop. 22, 183-190.

Drago, E.C. 1990. Geomorphology of large alluvial rivers: Lower Paraguay and Middle Paraná. Interciencia 15, 378-387.

Drago, E.C. 2007. The physical dynamics of the river-lake floodplain system. In: Iriondo, H., Paggi, J., Parma, J. [Eds] The Middle Paraná River. Limnology of a Subtropical Wetland. Springer, pp. 83-122.

Drago, E.C., Amsler, M.A. 1988. Suspended sediment at the cross section of the Middle Paraná River: concentration, granulometry and influence of the main tributaries. IAHS Spec. Publ. 174, 381-396.

Drago, E.C., Amsler, M.A. 1998. Bed sediment characteristics in the Paraná and Paraguay Rivers. Water Internat. 23, 174-183.

Drago, E.C., Vassallo M. 1980. Campaña limnológica "Keratella I" en el río Paraná Medio: Características físicas y químicas del río y ambientes leníticos asociados. ["Keratella I" limnological cruise along the Middle Paraná River: physical and chemical characteristics of the river waters and its floodplain lentic environments.] Ecología (Argentina) 4, 45-54.

Drago, E.C., Paira, A.R. 1997. Capítulo 1: Situación geohidrográfica del río Salado del Norte y estructura física de las principales subcuencas de su tramo inferior. [Chapter 1: Geohydrographical situation of the Salado del Norte River and the physical structure of their main subbasins in its lower reach.] In: Proyecto PID-BID CONICET No 230: Conservación y manejo de ecosistemas acuáticos continentales: contaminación y acuicultura. Informe Final (Período 1993-1996), Director: Prof. Inés Ezcurra de Drago. Instituto Nacional de Limnología (INALI-CONICET), Santo Tomé, Santa Fe, Argentina. pp. 12-69.

Drago, E.C., Ezcurra de Drago, I., Oliveros, O., Paira, A.R. 2003. Aquatic habitats, fishes and benthic assemblages of the Middle Paraná River. Amazoniana 17, 291-341.

Drago, E.C., Darrigran, G., Ezcurra Drago, I., Damborenea, C., Paira, A.R. 2006. Physical and chemical characteristics of the Pilcomayo, Bermejo and Salado del Norte rivers. In: Darrigan, G. [Project Director] Bioinvasion on the American Continent: Predicting Freshwater Bivalve Invaders. NGS Preliminary Report Grant \# 7824-05.

Drago, E.C., Paira, A.R., Wantzen, K.M. 2008. Channelfloodplain geomorphology and connectivity of the Lower Paraguay Hydrosystem. Ecohydrol. Hydrobiol. 8, ??-?? this issue.

Ezcurra de Drago, I. 1980. Campaña limnológica "Keratella I" en el río Paraná Medio: complejo bentónico del río y ambientes leníticos asociados. ["Keratella I" limnological cruise along the Middle
Paraná River: the bottom fauna of the river and its flood-plain water bodies.] Ecología (Argentina) 4, 89-101.

Ezcurra de Drago, I., Marchese, M., Wantzen, K.M. 2004. Benthos of a large neotropical river: spatial patterns and species assemblages in the Lower Paraguay and its floodplains. Arch. Hydrobiol. 160, 347-374.

Ezcurra de Drago, I., Marchese, M., Montalto, L. 2007. Benthic Invertebrates. In: Iriondo, M., Paggi, J., Parma, J. [Eds] The Middle Paraná River. Limnology of a Suptropical Wetland. Springer, pp. 251-275.

Fitzpatrick, F.A., Waite, I.R. D’Arconte, P., Meador, M., Maupin, M., Gurtz, M. 1998. Revised methods for characterizing stream habitat in the National WaterQuality Assesment Program. U. S. Geol. Surv., WaterResources Investigations Report 98-4052, Raleigh, North Carolina, USA.

Frissell, C.A., Liss, W.J., Warren, C.E., Hurley, M.D. 1986. A hierarchical framework for stream habitat classification: viewing streams in a watershed context. Environ. Manage. 10, 199-214.

Hamilton, S.K., Lewis, W.M. Jr. 1987. Causes of seasonality in the chemistry of a lake on the Orinoco River floodplain, Venezuela. Limnol. Oceanogr. 32, $1277-$ 1290.

Hamilton, S.K., Sippel S., Melack, J.M. 1996. Inundation patterns in the Pantanal wetland of South America determined from passive microwave remote sensing. Arch. Hydrobiol. 137, 1-23.

Holland, M.M. [Compiler] 1988. SCOPE/MAB technical report of a SCOPE/MAB workshop on ecotones. Biol. Int. 17, 47-106.

Holland, M.M. 1995. Challenges in managing fluvial ecotones. Ecol. Int. 22, 57-71.

Holland, M.M. 1996. Wetlands and environmental gradients. In: Mulamoottil, G., Warner, B.G., McBean, E.A. [Eds] Wetlands: Environmental Gradients, Boundaries, and Buffers, Lewis Publ., N. York, pp. 19-43.

HRS. 1972. River Paraguay Study: Hydraulic studies and mathematical model of the river between Asunción and Confluencia. Hydraulic Research Station (HRS), Report $\mathrm{N}^{\circ}$ EX 606, Wallingford, Berkshire, England.

Hynes, H.B. 1970. The Ecology of Running Waters, University of Toronto Press.

Junk, W.J., Bayley, P.B., parks, R.E. 1989. The flood pulse concept in river-floodplain systems. In: Dodge, D.P. [Ed.]. Proceedings of the International Large River Symposium, Canadian Special Publication of Fisheries and Aquatic Sciences 106, 110-127.

Lancelle, H., Longoni A., Ramos A., Cáceres, J. 1986. Caracterización físico-química de ambientes acuáticos permanentes y temporarios del Chaco Oriental. [Physical and chemical characterization of the permanent and temporary aquatic environments of the Eastern Chaco.] Ambiente Subtropical 1: 73-91. 
Marchese, M., Ezcurra de Drago, I. 1992. Benthos of the lotic environments in the Middle Paraná River System: transverse zonation. Hydrobiologia 237, 1-13.

Marchese, M., Ezcurra de Drago, I., Drago, E.C. 2002. Benthos invertebrates and physical habitat relationships in the Paraná River flood-plain system. In McClain, M. [Ed.]. The Ecohydrology of South American rivers and wetlands, IAHS Special Publ. 6, 111-132.

Marchese, M., Wantzen, K.M., Ezcurra de Drago, I. 2005. Benthic invertebrate assemblages and species diversity patterns of the Upper Paraguay River. River Res. Appl. 21, 485-499.

Mertes, L.A. 1997. Documentation and significance of the perirheic zone on inundated floodplains. Water Resour. Res. 33, $1749-1762$.

Orfeo, O. 1999. Sedimentological characteristics of small rivers with loessic headwaters in the Chaco, South America. Quaternary International 62, 69-74.

Paira, A.R., Drago, E.C. 2006. Genetical, morphological and evolutional relationships of the floodplain lakes in the Middle Paraná River hydrosystem. Zeitschrift für Geomorphologie 145, 207-228.

Paira, A.R., Drago, E.C. 2007. Origen, Evolution, and Types of Floodplain Water Bodies. In: Iriondo, M., Paggi, J., Parma, J. [Eds]. The Middle Paraná River. Limnology of a Suptropical Wetland. Springer, pp. 53-81.

Paola, C. 1997. When the streams collide. Nature 387, 232-233.

Petts, G., Amoros, C. 1996. Fluvial Hydrosystem. Chapman \& Hall, London.

Pringle, C.M. 2001. Hydrologic connectivity and the management of biological reserves: A global perspective. Ecol. Appl. 11, 981-998.
Risser, P.G. 1995. The status of the science examinating ecotones. BioScience 45, 318-325.

Rouse, H. 1961. Fluid mechanics for hydraulic engineer. Dover Publ. Inc., New York.

Schumm, S.A. 1977. The Fluvial System. John Wiley \& Sons, New York.

Schumm, S.A. 2005. River Variability and Complexity. Cambridge University Press, UK.

Tockner, K., Malard, F., Ward, J.V. 2000. An extension of the flood pulse concept. Hydrological Processes 14, 28612863.

Wantzen, K.M., Drago, E.C., da Silva, C.J. 2005. Aquatic habitats of the Upper Paraguay River-Floodplain System and parts of the Pantanal (Brazil). Ecohydrol. Hydrobiol. 5, 107126.

Ward, J.V. 1998. A running water perspective of ecotones, boundaries, and connectivity. Verh. Internat. Verein. Limnol. 26, 1165-1168.

Ward, J.V., Stanford J.A. 1995. Ecological connectivity in alluvial river ecosystems and its disruption by flow regulation. Regul. Rivers, 11, 105-119.

Ward, J.V., Wiens, J.A. 2001. Ecotones of riverine ecosystems: Role and typology, spatio-temporal dynamics, and river regulation. Ecohydrol. Hydrobiol. 1, 25-36.

Zalocar de Domitrovic, Y. 2002. Structure and variation of the Paraguay River phytoplankton in two periods of its hydrological cycle. Hydrobiologia 472, 177-196.

Zalocar de Domitrovic, Y., Devercelli, M., García de Emiliani, M.O. 2007. Phytoplankton. In: Iriondo, M., Paggi J., Parma, J. [Eds] The Middle Paraná River. Limnology of a Subtropical Wetland. Springer, pp.177-203. 